\title{
Europe Can No Longer Procrastinate
}

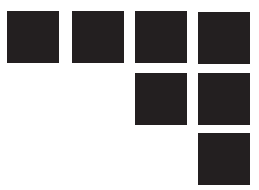

Fifteen years ago, the collapse of the bipolar world overwhelmed the installed world order. The USA became the only superpower standing and leading the world organization. They have now to deal with emerging countries such as China and India. On this chessboard, where is Europe?

The European project has had many successes since its birth in 1957 but has been deeply called into question by the rejection of the European Constitution by the French and the Dutch in 2005. That year Europe was unable to fix the future budget of the EU. Visibly, the developing process of the European project is often slowed down. The key question becomes what direction should Europe take to give itself a role in the world order of tomorrow. Many decisions have been delayed too long with Europe balking too often. The EU can no longer procrastinate. It must first identify the current issues in the organization of the European Union and then improve its efficiency and its quality.

In 1957, the purposes of peace and economic prosperity on the European Continent were fixed by the Rome Treaty. Today, these goals have been reached. However it is also clear today that these goals are not sufficient anymore and that they have to be redefined. There are obvious troubles in the European Union functioning, and moreover in the European project itself. First of all, the European bureaucracy is invasive and the European Commission is considered as a technocracy. This distances European citizens from European feelings.
The current functioning lacks democratic legitimacy and is in fact opposed to the proper definition of a democratic political power despite the European Parliament's certain role since its birth in 1979 and the Unique Act of 1985. The executive organ, the Commission, is not elected at all and the role of the Parliament is minimal. Moreover the national governments often present the European Union as a scapegoat, as if it was responsible for all the local problems. The European directive forbidding the traditional way some French cheeses are produced is a famous case in point. Indeed, the lack of transparency in the decisionmaking and financing process often creates euro-skepticism based on real feelings but fake ideas. People only see the EU as an invasive technocracy, which costs a lot and puts into question national traditions. Support for the European project has diminished. The now-fulfilled purposes of peace and economic prosperity have to evolve in order to bring back citizen support for EU reforms. The Executive branch also needs more transparency and democratic legitimacy. Actually, even if economic growth stays as a purpose, the challenges have changed. Europeans are today afraid of globalization, takeovers and relocations of their national firms, the loss of their national or local identity, international organized crime or the threat to their social protection model. And the problem is that they often do not believe Europe is facing these challenges. The European Commission and its management often intervene too much on a local scale. 
At the same time it does not manage to show efficiency in the fights with global problems, for instance Europol with crime. The Europeans fear being governed locally by the Commission, an institution they don't control at all. For instance, almost $75 \%$ percent of the laws voted at the French Parliament are only transcriptions of European directives established by experts and technocrats alone. The lack of democracy in the European functioning is consequently a determinant element that Europe has to deal with in the future. Europe has now to return to the idea its philosophers invented of representative democracy with representatives elected to establish the law governing countries. The current generation is now asking for a real political Union addressing all these new challenges. Europe must answer this. In addition, Europeans perception of the EU differs from the rest of the world's perception. For instance, Americans often conceive Europe as an all in one civilization sharing the same values and ways of life, a unified power. In contrast, Europeans more than ever think of themselves as members of their nations. It seems like the world was waiting for or already imagining a European political integration, a unified economic and diplomatic power far ahead of the European citizens themselves.

The difficulties of consolidating Europe also come from a lack of means that the Union gives itself. This issue is particularly evident in the financing process of Europe. The difficulties the European Council had in 2005 to fix the future budget of the Union are an example. It is important to notice that the members' contribution to the Union's budget represents only $1 / 40$ th of their national GDP. Nevertheless, Europeans maintain the idea that the European Union is expensive. European citizens should be taught this rate of contribution in order to better realize that the EU participation is incredibly low and should surely be increased. The Union shows on one hand a lack of democracy that creates a gap between the Executive organ and the European citizens; and on the other hand, a Union often accused of being too expensive for too little efficiency because of a lack of transparency in the financing functions. The EU does not live itself as a unified economic power. Europe does not have to become ultra-protectionist but the EU must answer the American and Chinese policies. For instance, European economic protection decreased since 1992 with the customs dues diminishing from $14 \%$ in 1992 to 1,5\% in 2006. Moreover exports are punished by the euro/dollar exchange rate. Once again, Europe has to conceive of itself as all in one, and not only as an accumulation of nations. Its future power depends on it if Europe wants to compete with the powers of today and tomorrow, the US and China who already practice aggressive exchange policies.

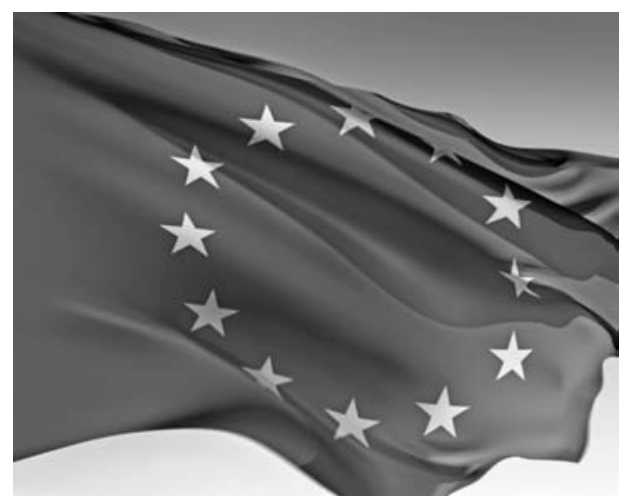

The same problems exist in the EU's foreign policy. For a long time, the EU has not spoken with a unified voice in the international scene. The debate on the Iraq war is emblematic. Europe was divided into pro-war (UK, Italy, Spain) and anti-war (France and Germany). This year further conflict erupted between French President Sarkozy, British Prime Minister Blair and Polish Prime Minister Kaczynski around the idea of naming the EU High Representative for the Common Foreign and Security Policy, EU Minister of Foreign Affairs. Europe is still far away from a unified 
European foreign policy, despite it being the only prospect for Europeans to have the right to sit at international tables and carry weight in the future. It is clear that each old European nation taken alone carries less and less weight in the world order. France and Germany's incapacity to bend US politics on Iraq highlight why EU nations will have to integrate and accept necessary compromises in order to influence a world order incorporating emerging superpowers whose incredible economic growth will surely become political power. The lack of democracy plays a role here. The debate on the Iraq war is again a case in point. European populationseventhosewhosegovernments supported the war demonstrated against the war. A real European democratic space where all would be debated and decided by representatives prior to being presented to the world by a Foreign Minister would be the unified voice of Europe. To adopt a common line is a necessary investment to build a real European diplomacy.

These issues call for more democracy, transparency and the integration of economic and diplomatic forces. Knowing this, what concrete ways can Europe take to reform? Two conceptions have always been debated since the Union's birth: the 'intergovernmental model' known as the "Europe of States" that Charles de Gaulle defended, in which Europe is firstly a free-trade zone and where the national governments keep their power; and the 'federalist model' where the national interests hide behind the European interest and where Europe and its citizens are considered as global. The EU has actually always navigated between these two conceptions. On the one hand, all the national divergences in foreign policy, between national fiscal systems, or in the financing process since the British discount of 1984 remain in the intergovernmental model. On the other hand, European citizenship and the free movement of people and capital are clearly federalist ideas. Europe has procrastinated too long and has now to choose a clear political line.

Two currentinteresting conceptions are found in the books of Jean-Pierre Chevènement's Mr. Monnet's Fault ${ }^{l}$ and Guy Verhofstadt's The United States of Europe ${ }^{2}$. Chevènement's conception remains that of a "Europe of States". However his theory doesn't only include the idea of national powers holding up against the community and the common interest. He actually explains all the virtues that he sees in the concept of a nation: the only space where democracy and its republican form can exist, where civil links and solidarity can be built. The nation taken as a mediator with the universal, where debate is possible and can become generalized after having been discussed at a national scale. He criticizes the Post-nationalist theory, and considers Jean Monnet guilty because he inspired the European construction with thoughts that preceded this theory. A theory in which the concept of the nation is enshrined, and where there is a fusion of the national sovereignties in a common one that creates instantly a common space for debate and democracy. Chevènement says this is an illusion and that, in fact, this theoretical model has actually led to the rise of regionalisms and micronationalisms and could lead to the constitution of tyrannical empires. Chevènement therefore advocates in favor of a "Europe of nations" with national debates and a strong FranceGermany duo leading the European project; but also in favor of a minor treaty that facilitates the institutional processes and a sort of European protectionism developing communal exchanges with a European economic government protecting exchanges and industry as a unified power.

In contrast, Guy Verhofstadt develops a clearly Federalist theory in the way he explains why he wants European countries to integrate more and more to create a real political union and then play a 
consequent role on the international scene. He shows how European citizens want a political union for Europe. Particularly when he analyzes the Eurobarometer probe of 2005 , in which $3 / 4$ of the citizens questioned agreed with the idea of a common Defense policy, 2/3 with a common Foreign policy, $1 / 2$ with the idea that Europe will play a role in their everyday life and in which a majority has the same fears of relocations and organized crime. Moreover, he makes a parallel with the way the constitution of the United States was established. American federalists were opposed to anti-federalists. Both groups were fighting to convince people of the good of a Federal State for one, of a Confederation for the other. Two elements were decisive in the adoption of the Federal Constitution. Firstly because the Federalists made the Americans understand to a majority that the War of independence could not have been won without the alliance of the thirteen colonies. Secondly, because the institutional process which allowed that the Constitution could be ratified by a majority of nine out of thirteen colonies voting was totally decisive. These two events are definitely reminiscent of the current situation in Europe: the need to ally to battle globalization and be heard on the international scene; the need of ratifications by qualified majorities for institutional evolutions in the EU. Verhofstadt concludes that the Federalist solution is the only way to deal with the economic growth of emerging countries that will become political powers, to deal with the challenge of the globalization and the challenge of Europe's ageing populations. According to him, to integrate Europe's national and social protection systems would be the only solution to regain competitiveness without any social or fiscal dumping. Finally there is a more and more recurrent option: the idea of two blocs developing in Europe. A big community of shared values as democracy and human rights, a big Europe maybe larger than the normal borders of Europe (including a Mediterranean Union) and above all an economic union, would see at its heart a political core with countries who want to integrate a political and federalist Europe.

The President of the European Commission José Manuel Barroso recently declared "before we decide how to spend money in the EU, we need to decide on the results we want. To decide on what the EU should achieve for its citizens". Whatever the way chosen may be, it is clear that Europe is definitely facing a time of decisive choices that will make the Union either restart or sink into its failures. The challenges of globalization, security, energy, and ageing populations are huge and Europe must simultaneously keep its tradition of solidarity and cooperation. The Union now has to adopt strategic and not just ideological views to influence the world order of tomorrow. For that, a political integration, with more democratic institutions and more transparency in the decision processes, seems essential to enshrine a common European belief.

\section{Endnotes}

1 Jean-Pierre Chevènement, La Faute de M.Monnet, Fayard, 2006

2 Guy Verhofstadt, Les Etats-Unis d'Europe, Ed. Luc Pire, 2006 